\title{
PŘEDMLUVA K POJEDNÁNÍ O PRÁZDNU ${ }^{1}$
}

\section{Blaise Pascal}

Do té míry dnes vzhlížíme ke Starověku ve věcech, v nichž úcta nemůže mít rozhodující slovo, že ve všem, nač pomyslel, vidíme proroctví a mystéria hledáme i tam, kde je mu těžké porozumět. Sotva pak můžeme razit cokoli nového, když je tu nebezpečí, že text nějakého autora je dost na to, aby zničil ty nejpevnější důvody...

Ne že bych zamýšlel jeden prohřešek napravovat druhým a Staré mínil nectít vůbec proto, že se to s úctou k nim přehání. Nehodlám zapovídat jejich autoritu, a tím vyzdvihovat jen úsudek samotný, i když by jiní rádi na úkor úsudku dosadili jen jejich autoritu...

Pokud toto důležité rozlišení máme vést důsledně, je zapotřebí uvážit, že jedny závisejí pouze na paměti a jsou ryze historické, jejich předmětem není nic víc než vědět, co autoři napsali. Další závisejí jen na úsudku a jsou veskrze dogmatické; jejich předmětem je hledání a odhalování skrytých pravd. Ty, co náležejí prvému druhu, jsou omezené stejně jako knihy, v nichž jsou obsaženy...

Toto rozlišení pak musí zodpovídat za to, jak daleko lze v oné úctě zajít. V úctě, kterou je třeba mít k...

V oborech, v nichž hledáme pouze vědění toho, co napsali autoři, jako jsou historie, zeměpis, právo, jazyky a zejména theologie a vposled všechny obory, jejichž principem je bud'to prostá skutečnost, anebo ustanovení Boží či lidské, se nevyhnutelně musíme uchylovat k jejich knihám, poněvadž vše, co o tom lze vědět, je v nich obsaženo. Odtud je zřejmé, že v těchto věcech můžeme mít úplnou znalost a že není možno k ní cokoli připojit.

Pokud jde o to, vědět, kdo byl prvním francouzským králem, kam zeměpisci umist'ují první poledník, jakých slov se užívalo v nějakém mrtvém jazyce a veškeré věci tohoto rázu, jak jinak bychom se k tomu mohli dobrat nežli prostřednictvím knih? A kdo bude s to doplnit něco k tomu, co nás knihy učí? Vždyt' vědět chceme jen to, co obsahují.

Poučit nás o tom může jedině autorita. Avšak oblastí, kde má tato autorita hlavní slovo, je theologie, poněvadž zde ji od pravdy nelze oddělit

1 B. Pascal, Préface sur la traité du vide, in: týž, Euvres complètes, I, vyd. M. Le Guern, Paris 2006, str. 452-458. 
a jedině skrze ni zde pravdu poznáváme. Pokud si totiž v těchto otázkách, jež jsou pro rozum navýsost nepochopitelné, chceme zjednat úplnou jistotu, stačí na ně poukázat ve svatých knihách - stejně tak, jako na nejistotu věcí vysoce pravděpodobných postačí poukázat už jen tím, že v nich obsaženy nejsou. Její principy totiž stojí nad přírodou i rozumem a lidský duch, poněvadž je př́liš slabý na to, aby k nim dospěl vlastním úsilím, se k těmto vrcholným nahlédnutím nemůže dobrat, není-li nesen nějakou všemocnou a nadpřirozenou silou.

Jinak tomu je v záležitostech smyslů či úsudku: tady autorita neslouží k ničemu, jejich poznání náleží jen samotnému rozumu. Jejich pravomoci jsou odděleny: výše mělo prvé všechno na své straně, druhé pak vládne zde. Poněvadž však předměty tohoto druhu jsou úměrné šir̂ii lidského ducha, je zcela svobodný k tomu se nad nimi rozepínat: ve své nevyčerpatelné plodnosti tvoří ustavičně a jeho objevy mohou být celkem vzato bez konce i bez přestání...

Tak je třeba, aby geometrie, aritmetika, hudba, fyzika, lékařství, stavitelství a všechny vědy podléhající zkušenosti a úsudku byly v zájmu své dokonalosti dále zmnožovány. Staří je od těch, kdo jim předcházeli, nalezli jen v náznacích a my je zas těm, kteří přijdou po nás, zanecháme o něco dokonalejší, než jak byly předány nám. A poněvadž jejich dokonalost závisí na čase a úsilí, je zjevné, že i kdyby se v našem čase a naším úsilím dosáhlo méně, než kolik přinesly jejich práce samotné, přesto oboje vespolek musí účinkovat více, než by tomu bylo u každého zvlášt'.

Jasnější nahlédnutí tohoto rozdílu nás musí vést k lítosti nad zaslepeností těch, kdo v otázkách fyziky namísto úsudku či pokusů jako důkaz předkládají jedině autoritu, a naplňovat zděšením před zlomyslností druhých, kteří ve věcech theologie užívají pouze úsudku namísto autority Písma a Otců. Je třeba dodat odvahy oněm bázlivcům, kteří si ve fyzice netroufají nic objevovat, a srazit domýšlivost opovážlivců, kteří novoty razí v theologii. Je však neštěstím doby, že se nám v theologii objevuje množství nových názorů, o nichž v celém Starověku nikdo neměl ani tušení, a přitom jsou umanutě zastávány a setkávají se s vřelým přijetím. Naproti tomu názory, které vytváŕíme ve fyzice, ačkoli nejsou mnohé, jako by ze lži nutně usvědčovalo už jen to, když se nepatrně odchylují od běžně zastávaných mínění. Jako bychom starověké filosofy snad měli ctít z povinnosti, zatímco úcta k nejstarším Otcům byla jen slušností! Ponechávám na rozumně smýšlejících lidech, aby sami nahlédli závažnost tohoto nešvaru, jenž tak nespravedlivě pokřivuje řád věd. Věřím pak, že se najde jen málo takových, kdo by si nepřáli, aby se této [svobody] užívalo v jiných oborech, poněvadž nové vynálezy jsou zaručeně chybné 
v záležitostech, které jsou beztrestně znesvěcovány, a poněvadž naprosto nezbytné jsou pro završení tolikerých dalších otázek, jež stojí nesrovnatelně níže, a přesto bychom se je neodvážili uchopit.

Odměřujme spravedlivěji mezi tím, čemu důvěřivě přitakáme, a před čím se máme na pozoru, a vytyčme hranice oné úctě, kterou Starým prokazujeme. Jelikož sama je dítětem rozumu, pak se též rozumem musí umírňovat. A uvažme, že kdyby oni sami ustrnuli v takové zdrženlivosti a neodvažovali se nijak přispět ke znalostem, jichž se jim dostalo; a kdyby u svých současníků naráželi na ten samý odpor k novotám, jež jim předkládali, pak by sami sebe i své potomky připravili o užitek ze svých objevů.

Poněvadž těch, které jim byly přenechány, užívali jen jako prostředků $\mathrm{k}$ dosažení nových, a díky této št'astlivé troufalosti si otevřeli cestu k velikým věcem, musíme stejným způsobem nakládat s objevy, které pro nás získali, učinit z nich po jejich vzoru prostředek, a nikoli cíl našeho bádání, a snažit se je tak překonat tím, že je napodobíme.

Je snad něco nespravedlivějšího nežli jednat s našimi Starými s větší zdrženlivostí, než jakou oni zachovávali vưči svým předchůdcům? A vzhlížet k nim s nedotknutelnou úctou, již si od nás vysloužili jenom tím, že obdobnou úctu neprokazovali těm, kdo měli stejnou výhodu vưči nim? ...

Tajemství přírody jsou skrytá, a třebaže koná ustavičně, její účinky ne vždy odhalíme. Vyjevují se časem v průběhu věků. A byt' sama v sobě je přiroda stále stejná, ne vždy je stejně poznána. Pokusů, které nám ji dovolují chápat, neustále přibývá; a protože jsou jedinými principy fyziky, úměrně $\mathrm{k}$ tomu přibývá $\mathrm{i}$ jejich důsledků.

A tak dnes můžeme, aniž bychom byli pohrdaví a nevděční, přijímat jiná stanoviska a nové názory, nebot' prvotní vědomosti, které nám předali, posloužily jako předstupeň $\mathrm{k}$ našim a skrze tuto výhodu jim dnes vděčíme za převahu, již vůči nim máme. Díky nim jsme se totiž povznesli až na jistou úroveň, odkud pak i sebenepatrnějším úsilím vystoupáme ještě výše, a za cenu menší námahy a bez větší slávy nad nimi nabýváme vrchu. Odtud pak můžeme objevit věci, které oni nemohli být schopni postřehnout. Náš pohled je širší, a třebaže právě tak dobře jako my věděli o všem, co v přírodě mohli zpozorovat, přesto o tom nevěděli tolik a my vidíme více.

Je ovšem zvláštní, jakým zpơsobem jejich názory uctíváme. Platí za zločin být $\mathrm{s}$ nimi v rozporu a cokoli $\mathrm{k}$ nim připojit se považuje za protiprávní jednání. Jako by už po nich nezůstaly žádné pravdy k poznání.

Zdali toto není nedůstojné zacházení s rozumem člověka? A nestaví se tím lidský rozum na úroveň zvîrecího instinktu, pokud jej připravíme 
o jeho hlavní odlišnost spočívající v tom, že důsledky usuzování se neustále zmnožují, kdežto $\mathrm{v}$ př́padě pudů zůstávají stále na té samé úrovni? Včelí plástve se před tisíci lety vyznačovaly právě tak dokonalou měrou, jakou mají i dnes. Každá ze včel utvářela onen šestiúhelník se stejnou přesností poprvé stejně tak jako naposled. Tak je tomu se vším, co živočichové z tohoto skrytého popudu konají. Příroda jim skýtá ponaučení, nakolik je k tomu pobízí nutnost. Avšak tato křehká věda zaniká spolu s potřebami, které ji u nich vyvolaly: poněvadž je jim dána bez studia, nemají to štěstí si ji podržet a vždy, kdy se jim této vědy dostane, pokaždé je nová; nebot' př́roda, jež tu nemá za cíl nic víc než udržet živočichy $\mathrm{v}$ jistém řádu omezené dokonalosti, jim v nezbytné a pokaždé v té samé mîre uděluje vnuknutí této vědy z obavy, aby nepropadali zániku, a nedovoluje jim k ní cokoli dodat $\mathrm{z}$ obavy, aby nepřestoupili hranice, které jim předepsala. Jinak je tomu u člověka, nebot' ten byl stvořen jedině pro nekonečno. V raných létech svého života spočívá v nevědomosti, avšak jak dále postupuje, neustále se vzdělává. Využívá totiž zkušeností nejen vlastních, ale i svých předchůdců, poněvadž poznatky, které jednou nabyde, si napořád uchovává v paměti a ty, co opatřili Staří, má stále před sebou na stránkách knih, jež nám zanechali. A protože si tyto znalosti drží, snadno je také může rozmnožit; a tak se nyní lidé v jistém smyslu nacházejí ve stejném postavení, v němž by se ocitli tito staří filosofové, kdyby jim bylo dáno stárnout až do dnešních dnů, a přitom ke svým stávajícím znalostem připojili ty, které by jim jejich studium zásluhou tolika staletí bývalo mohlo poskytnout. Proto se pak díky zvláštní výsadě nejen každý člověk zdokonaluje ve vědách, ale i všichni lidé jako celek tu procházejí nepřetržitým pokrokem s tím, jak vesmír stárne, nebot' v následnosti pokolení se děje to samé, co v různých životních údobích jednotlivce. A tak je třeba veškerou posloupnost lidí, jež přicházeli během tolika staletí, považovat za jednoho jediného člověka, který stále přetrvává a neustále se učí. Odtud je zjevné, jak velká je to nespravedlnost, když u těchto filosofů vzhlížíme k jejich starověkosti. Vždyt' je-li stáří věk, který leží nejdále od dětství, kdopak by neviděl, že stáří u tohoto universálního člověka bychom neměli spatřovat v období krátce po jeho narození, nýbrž v dobách od něj nejvzdálenějších? Ti, které nazýváme Starými, byli ve skutečnosti ve všem noví a ve vlastním smyslu tvořili dětství lidského rodu. A poněvadž my jsme k jejich znalostem přidali zkušenosti následujících staletí, lze tedy právě v nás nacházet onu Starověkost, kterou uctíváme u druhých.

Je na místě je obdivovat pro důsledky, jež se jim podařilo odvodit z toho mála principů, které měli ve své moci; a prominout jim tam, 
kde se jim spíše nedostávalo štěstí si je vyzkoušet, nežli schopnosti úsudku.

Nebylo snad možno je omluvit, že si o Mléčné dráze mysleli, když ještě slabosti jejich zraku nepřišel na pomoc důmysl, že ona barva vzniká vlivem vyšší hustoty v odpovídajících místech nebes, odkud se světlo odráží větší silou? Zůstalo by však nějaké omluvy pro nás, kdybychom při stejné myšlence setrvávali i nyní, kdy díky výhodám dalekohledu víme, že se zde nachází nekonečno drobných hvězd, a kdy nás jejich bohatší záře poučila o skutečné příčině této bělosti?

Neměli snad též dobrý důvod prohlašovat, že veškerá pomíjivá tělesa jsou zahrnuta $\mathrm{v}$ podměsíčné nebeské sféře, jestliže v průběhu tolika staletí mimo tento prostor nezaznamenali žádný případ zániku ani vzniku? Avšak neměli bychom my tvrdit opak, pokud celý svět zřetelně spatřil, jak hluboko za touto sférou vzplály a zanikly komety?

Takto pak i ve věci prázdna mohli právem říci, že příroda je nesnáší, poněvadž veškeré poznatky jejich zkušenosti svědčily vždy o tom, že k němu má odpor a nedokáže je strpět. Avšak kdyby jim byly známy naše nové pokusy, možná by nalezli důvod tvrdit to, co měli důvod popírat, jelikož prázdno do té doby nikdo neviděl. A tak pokud soudili, že příroda prázdno nesnáší, na mysli měli prŕrodu pouze v tom stavu, jak ji znali, nebot' aby to bylo možno říci obecně, nestačilo by to pozorovat bez výjimky ve stech různých případech, ani v tisíci a ani v žádném dalším, jakkoli vysokém počtu. I kdyby totiž zbývalo prozkoumat jeden jediný případ, už jen ten by zamezoval obecné definici, a kdyby se jen jeden vymykal, už jen ten...

Nebot' u všech otázek, jež se dokazují za pomoci pokusů, a nikoli demonstrativně, se universální výpovědi nelze dobrat jinak než celkovým výčtem všech součástí anebo všech jednotlivých případů. Takto když říkáme, že diamant je nejtvrdším tělesem ze všech, myslíme tím ze všech těles, která známe, a nemůžeme, a ani nesmíme v to počítat ta, která neznáme; a když říkáme, že zlato je nejtěžší ze všech těles, byla by od nás opovážlivost zahrnovat v tento obecný výrok i tělesa, o nichž dosud nemáme žádnou znalost, byt' není nemožné, že se v přírodě vyskytují.

A právě tak když Staří tvrdili, že příroda prázdno nesnáší, mínili tím, že tomu tak je ve všech pozorovaných prrípadech, kam by ovšem, aniž by se dopustili troufalosti, nemohli počítat ty, jež spadaly mimo jejich poznání. Kdyby je znali, nepochybně by odtud vyvodili stejné závěry jako my a svým přitakáním by jim dodaly punc oné Starověkosti, jež má dnes být jediným principem věd. 
Proto můžeme, aniž jim protiřečíme, tvrdit opak toho, co říkali, a at' už má ona Starověkost vposled jakoukoli moc, pravda vždy musí mít přednost, byt' byla teprve objevena, nebot' bude vždy starobylejší než všechny názory, které jsme si o ní utvořili, a znamenalo by to neznat její povahu, pokud bychom si představovali, že začala být teprve tehdy, jakmile začala být známa.

Přeložil Jan Makovský 